\title{
Upaya Cina menjadi Kekuatan Maritim dalam Indian Ocean Rim Association (IORA)
}

\author{
Umi Qodarsasi ${ }^{1}{ }^{1}$ Tety Rachmawati ${ }^{2}$ \\ ${ }^{1}$ Program Studi Pemikiran Politik, IAIN Kudus, Jawa Tengah - Indonesia \\ ${ }^{2}$ Jurusan Hubungan Internasional, Universitas Lampung - Indonesia \\ Email: umiqodarsasi@gmail.com \\ Diserahkan: 03 September 2018 | Diterima: 03 Oktober 2018
}

\begin{abstract}
After the economic reform in 1978, China experienced a rapid economic growth. The open door policy adopted on economic reforms succeeded in attracting many foreign investors in the sector of manufacture. Along with its status as a new power of the world economy, China is also ambitious to become the largest maritime power. The Indian Ocean is a strategic area to strengthen China's steps to support economic needs and become a maritime power. To achieve strategic interests in the Indian Ocean Region, China joins as an IORA partner. China's effort to dominate at the IORA is not only to recruiting rival countries, but also to built strategic partnerships with the countries in the Indian Ocean region. Besides Pakistan and Myanmar, China has also established strategic partnerships with Iran, Bangladesh and Sri Lanka. For strategic partner, China is seen as an alliance in strengthening politics in their country and is a supplier of military weapons and technology with affordable prices. This paper will explain the China's interests in the IORA and China's position compared to other IORA member, and also China's strategy. The results obtained shows that China has the potential to become a maritime power at the IORA.
\end{abstract}

Keywords: Emerging, Economy, IORA, Maritime, Power.

\begin{abstract}
Abstrak
Pasca reformasi ekonomi pada tahun 1978, Cina mengalami pertumbuhan ekonomi yang pesat. Strategi open door policy yang diadopsi sejak reformasi ekonomi berhasil menarik banyak investor asing dalam sektor industri manufaktur. Seiring dengan status sebagai kekuatan baru perekonomian dunia, Cina juga berambisi menjadi kekuatan maritim di kawasan Samudera Hindia. Samudera Hindia merupakan kawasan strategis bagi Cina untuk mendukung kebutuhan ekonomi dan sebagai kekuatan maritim. Dalam upaya mencapai kepentingan strategis di kawasan tersebut, Cina bergabung menjadi mitra IORA. Upaya dominasi Cina di IORA selain untuk merespon negaranegara pesaingnya, juga membangun kemitraan strategis dengan negara-negara di wilayah Samudera Hindia, seperti Pakistan dan Myanmar. Cina juga menjalin kemitraan strategis dengan Iran, Bangladesh dan Sri Lanka. Bagi negara mitra strategis, Cina dipandang sebagai aliansi dalam memperkuat politik di negara mereka dan merupakan pemasok senjata militer serta teknologi dengan harga terjangkau. Dalam tulisan ini akan dijelaskan kepentingan Cina di IORA, posisi Cina dibanding anggota lainnya, dan strategi maritim Cina dalam IORA. Hasil yang diperoleh menunjukkan bahwa Cina sangat berpotensi menjadi maritim power di IORA.
\end{abstract}

Kata Kunci: Ekonomi, Baru, IORA, Kekuatan, Maritim

\section{PENDAHULUAN}

Samudera Hindia merupakan samudera terluas ketiga di dunia yang menyelimuti 20 persen dari total samudera di dunia. Samudera Hindia 
membentang seluas lebih dari 10.000 $\mathrm{km}$ dari ujung selatan Benua Afrika sampai ke pantai Barat Australia.

Dengan luas wilayah yang mencapai 28 juta $\mathrm{km}$ persegi, Samudera Hindia menjadi tuan rumah bagi sepertiga populasi di dunia, dan menjadi lalu lintas sebagian besar aktivitas perdagangan dunia. Samudera Hindia merupakan jalur utama yang menghubungkan antara Eropa dan Amerika dengan wilayah Timur Tengah, Afrika, dan Asia Timur. Samudera Hindia menyimpan kekayaan produk minyak, produk kelautan dan mineral. Hampir 40 persen total produksi minyak lepas pantai berasal dari Samudera Hindia. Samudera Hindia selalu menjadi wilayah penting bagi perdagangan, keamanan, dan sumber daya kelautan negara-negara pesisir dan serta kekuatan dunia yang dominan saat itu. Pelayaran Samudera Hindia dari Timur Tengah ke Timur Pasifik menyumbang 50 persen dari lalu lintas peti kemas dan 70 persen lalu lintas produk minyak bumi untuk seluruh dunia (Kaplan, 2011， 7). Cina melalui perusahaan yang sama karena 85 persen dari minyak impornya melalui Samudera Hindia (Kapoor \& Bajpai, 2014).

Kawasan Samudera Hindia selalu menjadi wilayah yang sangat penting untuk perdagangan, keamanan, dan sumber daya kelautan bagi negara- negara pesisir Samudera Hindia maupun negara-negara besar di dunia. Pasca Perang Dingin terjadi perubahan dinamika kekuatan di Samudera Hindia, Cina dan India muncul sebagai kekuatan baru dan menjadi pesaing baru bagi Amerika Serikat yang sebelumnya mempunyai dominasi di wilayah ini. Cina dan India terus meningkatkan kerja sama dengan negara-negara di wilayah Samudera Hindia, memelihara perekonomian serta tatanan politik di negara-negara tersebut.

Pasca reformasi ekonomi pada tahun 1978, Cina mengalami pertumbuhan ekonomi secara signifikan, sehingga berhasil mengubah status dalamperekonomian global, yakni sebagai the emerging economy. Bahkan para analis memprediksi Cina akan mengambil alih posisi Amerika Serikat sebagai kekuatan ekonomi terbesar di dunia. IMF memprediksi bahwa pada tahun 2019 ekonomi Cina akan 21,3\% lebih besar dibandingkan dengan Amerika Serikat (Yi-Min, 2014, 1-2). Seiring dengan meningkatnya perekonomian, maka pengaruh dan posisi Cina sebagai kekuatan global juga meningkat. Di samping pasar domestik yang sangat besar, Cina juga mendorong perekonomiannya melalui perdagangan dan investasi global sekaligus memenuhi kebutuhan energi dari sumber eksternal, yaitu dari 
negara-negara berkembang yang menyimpan sumber daya alam yang melimpah.

Seiring dengan status sebagai kekuatan ekonomi baru, Cina berambisi menjadi kekuatan maritim terbesar di dunia sebagai bagian dari kepentingan nasional. Hal ini disampaikan oleh Presiden $\mathrm{Hu}$ Jintao secara resmi dalam kongres ke 18 Partai Komunis Cina dengan menyatakan bahwa mewujudkan Cina sebagai kekuatan maritim dunia merupakan prioritas utama Partai Komunis Cina. Hal serupa juga ditegaskan oleh penerusnya, yaitu presiden Xi Jinping yangmenyebutkan akan memobilisasi negara untuk mengambil tindakan aktif melindungi hak dan kepentingan maritim Cina (Kardon, 2015).

Samudera Hindia merupakan kawasan strategis bagi kepentingan Cina, selain untuk mendukung perekonomian, juga untuk memantapkan langkah Cina sebagai maritime power. Seiring dengan meningkatnya perekonomian Cina, maka meningkat pula kebutuhannya akan energi dan sumber daya alam. Hal ini mendorong Cina untuk memantapkan kembali langkah strategis kawasan Samudera Hindia sebagai kawasan yang kaya akan energi dan sumber daya alam, sebagaimana jejak sejarah kejayaan kekaisaran Cina dalam aktivitas perdagangan di Jalur
Sutera ini. Cina menjadi mitra dalam Indian Ocean Rim Association (IORA) yang beranggotakan negara-negara di pesisir atau lingkar Samudera Hindia. Mitra dialog IORA lainnya yaitu Amerika Serikat, Cina, Inggris, Jepang, Mesir, dan Perancis. (IORA, 2017). Untuk bisa mencapai kepentingan maritim dan memenuhi kebutuhan sumber daya alam di Kawasan Samudera Hindia, Cina harus bersaing dengan negara-negara mitra dialog lainnya, terutama dengan Amerika Serikat.

\section{CINA SEBAGAI KEKUATAN EKONOMI BARU}

Emerging Economic Power atau kekuatan ekonomi baru merupakan perluasan makna dari emerging power. Emerging power diartikan sebagaisebuah negara dengan seperangkat atribut material dan ideasional dengan tindakan politik yang spesifik, sebuah aktivisme reformis dan revisionis dalam tatanan internasional. Terjadi pergeseran posisi bagi emerging power dalam tatanan dunia. Cina digolongkan sebagai emerging power dengan pertumbuhan ekonomi yang cukup signifikan. Pertumbuhan ekonomi Cina yang pesat dimulai dari kebijakan reformasi ekonomi yang digagas oleh Deng Xiaoping pada tahun 1978. Standar hidup penduduk Cina mengalami kenaikan. Pada tahun 1998, World Bank merubah status Cina dari 
low income menjadi lower middle income. Sejak adanya reformasi, pasar secara perlahan tumbuh sebagai pusat aktivitas ekonomi. Hal ini berdampak positif terhadap tumbuhnya jumlah industri dan iklim kompetisi perdagangan. Pada tahun 1978, jumlah industri Cina hanya sebanyak 1,2 juta, namun dua puluh tahun kemudian jumlah industri mencapai 8 juta. Strategi open door policy yang diadopsi pada reformasi ekonomi berhasil menarik banyak investor asing. Berawal dari industri manufaktur dengan sedikit konsumen, pasca reformasi industri Cina berkembang pesat dan bergerak di berbagai sektor dengan pasar yang besar (Yi-Min, 2014, 1-2).

Reformasi ekonomi Cina terdiri dari tiga pilar. Pilar pertama diimplementasikan pada akhir tahun 1978 dengan kebijakan pemerintah memberikan insentif pasar terhadap produk pertanian. Pemerintah memberikan insentif harga dan kepemilikan tanah bagi para petani, yang memungkinkan mereka untuk dapat menjual hasil panen di pasar bebas. Pemerintah mendorong produksi pertanian sebagai respon terhadap permintaan dan harga pasar, berbeda dengan sebelumnya di mana pemerintah mendorong produksi hanya untuk memenuhi target produksi. Reformasi sektor pertanian ini sukses meningkatkan produktivitas pertanian dan pendapatan petani. Melalui reformasi ini pemerintah juga membebaskan buruh desa untuk melakukan urbanisasi (Yi-Min, 2014, 3-4).

Pilar kedua diimplementasikan pada tahun 1984 dengan kebijakan insentif pada sektor manufaktur melalui program The Enterprise Responsibility System. Program ini mendorong perusahaan untuk mengatur dan memegang kendali seperti perusahaan berbasis profit lainnya. Perusahaan dapat memperoleh masukan atau bahan produksi dari pasar dan menjual produksinya di pasar dengan harga yang ditentukan oleh pasar. Ini berbeda dengan sebelumnya di mana masukan dan keluaran ditentukan oleh badan-badan milik pemerintah sesuai dengan harga yang telah ditetapkan. Pemerintah mengurangi subsidi produksi dan mendorong perusahaan untuk menggunakan bank dalam memenuhi kebutuhan modal.

Pengurangan dukungan dana dari pemerintah mendorong perusahaan untuk lebih berorientasi pada keuntungan. Pada tahun 1996, sekitar 9,4 juta perusahaan beroperasi dalam perekonomian Cina. Sebagian besar keluaran industri dihasilkan oleh perusahaan swasta dan sebagian kecil dihasilkan oleh perusahaan milik pemerintah (Oatley, 2012, 152-153). 
Pilar ketiga adalah Kebijakan Pintu Terbuka (Open Door Policy) tahun 1979. Kebijakan Pintu Terbuka menghubungkan Cina dengan perekonomian global melalui liberalisasi perdagangan dan investasi asing. Strategi ini merupakan sebuah upaya untuk mendorong bisnis dan investasi Cina agar berekspansi ke luar negeri dan masuknya investasi asing ke dalam negeri. Untuk menarik investor asing, mendorong ekspor, dan meningkatkan impor produk berteknologi tinggi, Pemerintah Cina mendirikan daerah ekonomi khusus atau special economic zones (SEZs) di sepanjang pantai selatan Cina dan akan diperluas ke seluruh daerah pantai lainnya di Cina. Dalam SEZs, pemerintah mengizinkan lebih banyak aktivitas berbasis pasar bebas dibandingkan dengan wilayah ekonomi lainnya. Pemerintah mengurangi beacukai dan pajak, mendorong perusahaan-perusahaan swasta untuk beroperasi, dan melonggarkan pembatasan buruh. Kontrol terhadap perusahaan diberikan kepada pemerintah lokal maupun provinsi dengan izin untuk beroperasi dan berkompetisi dalam prinsip pasar bebas (Ming, 2008, 254255).

Tiga pilar tersebut mengantarkan Cina meraih pertumbuhan ekonomi yang cukup signifikan. Berikut grafik pertumbuhan ekonomi Cina yang ditunjukkan dengan perbandingan GDP per kapita dengan negara-negara ekonomi terbesar lainnya di dunia (Ross, 2017).

Grafik. 1 Pertumbuhan Ekonomi Cina

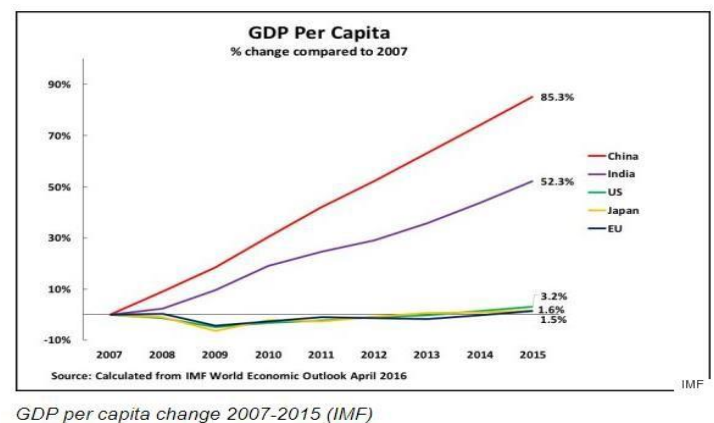

\section{NILAI STRATEGIS IORA BAGI CINA}

Indian Ocean Rim Association (IORA) yang sebelumnya bernama for Indian Ocean Rim Association Regional Cooperation (IORARC) merupakan inisiatif kerja sama regional negaranegara di kawasan pesisir Samudera Hindia. Relasi antara negara-negara di pesisir Samudera Hindia dipengaruhi oleh faktor historis di mana negaranegara tersebut sudah menjalin interaksi sejak beberapa abad yang lalu melalui perdagangan, pelayaran, dan ziarah. Selain itu negara-negara tersebut juga mempunyai kesamaan pengalaman sejarah yaitu berada di bawah imperialisme Bangsa Eropa. Kedekatan ini yang mendorong sejumlah negara di kawasan Samudera Hindia untuk meningkatkan kerja sama sosial-ekonomi demi kemajuan kawasan (Roza, 2015). 
Secara formal, IORA pertama kali diresmikan pada pertemuan tingkat Menteri di Mauritius pada 6-7 Maret 1997. Charter of the Indian Ocean Rim Association merupakan dokumen yang menjadi dasar IORA. Samudera Hindia merupakan kawasan heterogen dengan beragam bahasa, budaya, dan agama. Negara-negara di kawasan ini juga mempunyai beragam luas wilayah dan kekuatan ekonomi. Banyak negara anggota IORA yang memiliki kapasitas untuk berkompetisi dalam tingkat global dan terus menggali kapasitas baru lainnya yang bisa dimanfaatkan untuk kepentingan kerja sama regional. Negara-negara tersebut mempunyai potensi sumber daya manusia dan teknologi yang besar. Selain menjadikan IORA sebagai organisasi yang bebas dalam keikutsertaannya dalam membangun ekonomi kelautan kawasan yang berdasarkan konsensus bersama, IORA juga mempunyai tujuan.

Pertama, mempromosikan pertumbuhan yang berkelanjutan dan pembangunan yang seimbang di kawasan dan negara-negara anggota, dan untuk menciptakan landasan bersama bagi kerja sama ekonomi regional.

Kedua, memusatkan perhatian pada bidang kerja sama ekonomi yang memberikan kesempatan maksimal untuk mengembangkan kepentingan bersama dan menuai keuntungan bersama. Untuk mencapai tujuan ini, untuk merumuskan dan melaksanakan proyek untuk kerja sama ekonomi yang berkaitan dengan fasilitasi perdagangan dan liberalisasi, promosi investasi asing, pertukaran ilmiah dan teknologi, pariwisata, pergerakan orang perseorangan dan penyedia layanan secara non-diskriminatif; dan pengembangan infrastruktur dan sumber daya manusia antar aliasi, pengentasan kemiskinan, promosi transportasi maritim dan hal-hal terkait, kerja sama di bidang perdagangan perikanan, penelitian dan manajemen, budidaya, pendidikan dan pelatihan, energi, TI, kesehatan, perlindungan lingkungan, pertanian, manajemen bencana.

Ketiga, menghidupkan bidang prioritas yang meliputi keselamatan dan keamanan maritime, fasilitasi perdagangan dan investasi; manajemen perikanan, manajemen risiko bencana, kerjasama akademik, ilmu pengetahuan \& Teknologi, dan Bursa Pariwisata dan Budaya.

Keempat, menjelajahi semua kemungkinan dan jalan untuk liberalisasi perdagangan, untuk menghilangkan hambatan, dan hambatan yang lebih rendah terhadap, arus barang, jasa, investasi, dan teknologi yang lebih bebas dan lebih baik di wilayah ini. 
Kelima, mendorong interaksi yang erat antara perdagangan dan industri, institusi akademis, ilmuwan dan masyarakat dari negara-negara anggota tanpa adanya diskriminasi di antara negara-negara anggota dan tanpa mengurangi kewajiban berdasarkan pengaturan kerjasama ekonomi dan perdagangan regional lainnya.

Keenam, memperkuat kerja sama dan dialog antar negara-negara anggota dalam forum internasional mengenai isu-isu ekonomi global, dan bila diinginkan untuk mengembangkan strategi bersama dan mengambil posisi bersama dalam forum internasional mengenai isu-isu kepentingan bersama.

Ketujuh, mempromosikan kerja sama dalam pengembangan sumber daya manusia, terutama melalui hubungan yang lebih erat antara institusi pelatihan, universitas dan institusi khusus lainnya dari negaranegara anggota (Piagam IORA).

Selain tujuan utamanya yaitu mendorong kerja sama ekonomi regional, di bawah kepemimpinan India pada tahun 2012-2013, IORA memperluas sasaran menjadi enam bidang prioritas kerja sama, yaitu : 1) Keamanan dan Keselamatan; 2) Perdagangan dan Fasilitasi Investasi; 3) Manajemen perikanan; 4) Manajemen Resiko Bencana; 5) Akademik, Sains dan Teknologi; serta 6) Pariwisata dan Pertukaran Budaya. IORA juga telah mengidentifikasi dua tema lintas sektoral, yaitu pemberdayaan gender dan ekonomi biru (blue economy).

Blue economy mendorong penggunaan sumber daya laut berkelanjutan, seperti perikanan, hidrokarbon lepas pantai, dan deposit mineral. Blue economy ini sangat penting bagi IORA dan ditekankan dalam dokumen-dokumen IORA seperti The Perth Consensus of 2014 dan The Mauritius Blue Economy Declaration of 2015. Pengembangan sumber daya laut berkelanjutan harus sejalan dengan kerangka yang telah ditetapkan oleh United Nations (UN) Convention on the Law of the Sea, dan dengan menekankan pentingnya memfasilitasi usaha mikro, kecil dan menengah (Waidyatilake, 2017).

Semua negara berdaulat dari kawasan sekitar Samudera Hindia berhak untuk menjadi anggota Asosiasi. Untuk menjadi anggota, negara harus mematuhi prinsip dan tujuan yang tercantum dalam Piagam Asosiasi. Perluasan keanggotaan Asosiasi akan diputuskan oleh negaranegara anggota. Kemudian Dewan Menteri dapat memberikan status Mitra Dialog atau Pengamat ke Negara Bagian atau Organisasi lain, yang memiliki kapasitas dan kepentingan untuk berkontribusi pada IORA. Saat ini IORA mempunyai 21 anggota 
antara lain, Australia, Bangladesh, Uni Komoro, India, Indonesia, Iran, Kenya, Malaysia, Madagaskar, Mauritius, Mozambik, Oman, Seychelles, Singapura, Somalia, Afrika Selatan, Sri Lanka, Tanzania, Thailand, Uni Emirat Arab, dan Yaman. IORA juga mempunyai mitra dialog dan pengamat. Mitra dialog IORA yaitu Cina, Mesir, Perancis, Jepang, Inggris, dan Amerika Serikat. Sementara pengamat IORA terdiri dari Indian Ocean Research Group (IORG) dan Indian Ocean Tourism Organization (IOTO) (Indian Ocean Rim Association for Regional Cooperation, 2013).

IORA mempunyai nilai yang sangat strategis bagi Cina. Secara umum, ada enam kepentingan maritim Cina. Pertama, Cina ingin mengamankan pulau-pulau lepas pantai, salah satunya adalah Taiwan, Cina memiliki kepentingan strategis di pulau ini dalam konteks politik maupun ekonomi. Cina ingin menyatukan kedaulatan bagian-bagian Cina yang terpisah. Pemerintah Cina menganggap Taiwan merupakan bagian dari Cina daratan dan harus menjadi bagian dari wilayah negaranya. Sementara Taiwan bersikeras bahwa hubungan antara Taiwan dengan Cina merupakan hubungan antar negara bukan hubungan antara pemerintah pusat dengan propinsinya. Taiwan melihat upaya reunifikasi oleh Cina hanya dapat terjadi jika Cina menjadi negara yang demokratis. Cina kemudian menegaskan bahwa setiap negara yang ingin menjalin hubungan diplomatik dengan Cina maka harus memutuskan hubungan diplomatik dengan Taiwan, karena Taiwan merupakan wilayah teritorialnya (Dingli, 2013).

Kedua, Cina berkepentingan mengamankan wilayah, perairan, dan ruang territorial yang menyebar sepanjang $18.000 \mathrm{~km}$ agar tetapberada di bawah kendali negara. Dengan wilayah perairan yang cukup luas, banyak potensi kerugian yang timbul, seperti perompakan, penyelundupan, dan tindakan-tindakan lainnya yang mengancam stabilitas dan keamanan negara. Oleh karena itu, melalui kerja sama dengan negara-negara anggota IORA, potensi munculnya aktivitas yang merugikan dan membahayakan wilayah bisa diminimalisir atau dicegah secara bersama-sama melalui kesepakatan-kesepakatan dan kerja sama.

Ketiga, pasca pembentukan The United Nations Convention on The Law of The Sea (UNCLOS) pada 1982 membuat hak ekonomi maritim Cina semakin besar, untuk itu Cina harus memastikan bahwa kawasan maritim Cina harus dikelola secara eksklusif dan berkelanjutan, Zona Ekonomi Eksklusif Cina bisa jadi bersinggungan dengan negara tetangga sehingga dibutuhkan dialog bilateral untuk 
mengatasi tumpang tindih kepentingan, juga untuk menghindari konflik. Keempat, Posisi Cina sebagai pengekspor dan pengimpor utama perdagangan dunia mendorong Cina untuk memastikan akses gratis jalur laut sebagai jalur perdagangan. Pada tahun 1996, Cina menjadi pengimpor besar minyak mentah. Antara tahun 1999-2009, konsumsi minyak Cina meningkat sebanyak dua kali lipat. Bagi Cina, $80 \%$ impor perminyakannya melewati jalur Selat Malaka yang disebut sebagai "lifeline" pembangunan ekonomi Cina. Untuk mengatasai kerentanan pasokan energi maka Cina melakukan diversifikasi pemasok energi dan mengembangkan rute transit lainnya, termasuk jalur pipa darat sebagai sarana transportasi alternatif bagi kebutuhan energinya (Hatcher, 2013).

Kelima, menghormati hak-hak maritim sesuai dengan hukum internasional yang relevan. Di bawah hukum internasional dalam bidang kemaritiman, negara-negara mempunyai batasan-batasan yang jelas dalam pengelolaan wilayah maritim. Cina memiliki sengketa maritim dengan beberapa negara tetangga di Samudera Pasifik, maka di Samudera Hindia Cina menjalin kemitraan strategis dengan negara-negara IORA agar terhindar dari konflik dan agar bisa mendapatkan kepentingannya. Keenam, ketika menghadapi berbagai sengketa maritim, Cina akan memanfaatkan seperangkat alat hukum dengan mengedepankan perdamaian (Dingli, 2013). Dengan adanya kerja sama regional, maka ada forum untuk menyelesaikan masalah sengketa tersebut dengan mengedepankan negosiasi.

Cina memahami bahwa Amerika Serikat dan India memiliki posisi yang lebih penting di Kawasan Samudera Hindia. Untuk menguatkan posisinya, Cina menginisiasi kebijakan mencari fasilitas angkatan laut dan kemitraan strategis dengan negara-negara pesisir di sekitar India. Selain menjalin kemitraan strategis dengan negaranegara pesisir IORA, Cina terus bergerak melakukan modernisasi angkatan laut secara cepat dalam dua dekade terakhir serta meningkatkan penyebaran angkatan laut secara strategis di kawasan Samudera Hindia. Meningkatnya pembajakan di teluk Eden mendorong Cina mengerahkan pasukan angkatan lautnya di kawasan ini untuk melawan pembajakan. Cina mengerahkan kapal-kapal, helikopter dan pasukan khusus bersenjata. Modernisasi dan peningkatan penyebaran laut ini bertujuan untuk meningkatkan keamanan dan keselamatan kawasan Samudera Hindia dari perompakan di mana mendatangkan kerugian yang besar dan kerusakan sumber daya laut (Kapoor \& Bajpai, 2014). 


\section{UPAYA CINA MENJADI KEKUATAN MARITIM MELALUI IORA}

Maritim power merupakan terminologi yang terdiri dari dua kata yaitu maritime dan power. Maritim mengacu pada beberapa elemen seperti pelabuhan, armada niaga, sumber daya laut dan armada angkatan laut (Ahmed, 2014). Power mengacu pada elemen kekuatan, pengaruh, dan kekuasaan. Jadi, maritim power diartikan sebagai semua elemen maritim yang berpengaruh pada kekuatan nasional (Ahmed, 2014). Sedangkan strategi maritim adalah semua hal yang berkaitan dengan laut dan manajemen aset yang memungkinkan negara belajar dan mengaplikasikan skillnya.

Seperti yang telah diketahui bersama bahwa laut memiliki sumber daya alam dan potensi yang sangat besar. Laut setidaknya memiliki tiga potensi yaitu ekonomi, militer, dan politik. Dalam bidang ekonomi laut menjadi penyedia sumber daya alam yang cukup banyak sekaligus tempat industri seperti industri pengalengan ikan. Selain itu, laut adalah jalur yang paling banyak digunakan untuk aktivitas perdagangan. Sekitar 90\% aktivitas perdagangan dilakukan melalui jalur laut (Ahmed, 2014). Dalam bidang militer laut dapat digunakan untuk berbagai keperluan militer seperti latihan perang dan uji coba penemuan senjata perang seperti misil. Bagi beberapa negara, laut juga merupakan batas pertama yang harus dilalui sebelum perang di daratan. Oleh karena itu, keberadaan laut sangat strategis bagi pertahanan dan keamanan sebuah negara. Selain bidang ekonomi dan militer, laut juga penting jika dilihat dari perspektif politik. Sebuah negara yang memiliki akses ke laut, cenderung memiliki suara dan pengaruh di bidang perdagangan internasional, seperti menetapkan harga transportasi laut, menetapkan kebijakan pengiriman dan pergantian barang, dan lain-lain.

Sebelum membahas berkaitan dengan strategi Cina untuk menjadi maritime power di kawasan regional IORA, terlebih dahulu akan dibahas posisi negara anggota IORA. Hal ini dimaksudkan untuk melihat potensi Cina sebagai maritim power di IORA.

\section{KEDUDUKAN CINA DAN NEGARA KEKUATAN KAWASAN LAINNYA}

Regional $\begin{gathered}\text { power } \\ \text { (kekuatan } \\ \text { regional) merupakan }\end{gathered}$
terminologi dalam $\begin{array}{r}\text { hubungan } \\ \text { internasional yang mengacu pada }\end{array}$
sebuah kekuatan negara yang mampu
memberikan pengaruh dalam suatu
regional (wilayah). Regional power
memiliki kapasitas militer, ekonomi,
politik, dan ideologi yang mampu
memengaruhi agenda keamanan


regional. Dalam perspektif NeoGramscian menyebutkan bahwa regional power dapat tumbuh menjadi hegemoni yang mampu memberikan pengaruh dalam sistem global.

Pada awal kemunculannya, terminologi regional power mendorong perdebatan di antara para ilmuan. Keberadaan terminologi tersebut sebagai respons dari munculnya kekuatan ekonomi baru (new emerging economic power) di awal abad 21. Salah satu perdebatan ilmuan ini didasarkan pada pemahaman mengenai definisi regional power, karena negara-negara yang tergolong sebagai regional power juga digolongkan sebagai middle power. Detlef Nolte menyatakan bahwa konsep middle power dalam konsepsi tradisional merupakan negara-negara yang pertama kali digolongkan sebagai middle power, sedangkan middle power dalam konsepsi kontemporer saat ini lebih dikenal dengan sebustan regional power (Nolte, 2010, 890). Berbeda dengan middle power, regional power bertanggungjawab terhadap tatanan keamanan di suatu kawasan.

Jika dilihat dari bidang ekonomi, militer dan stabilitas politik, dari 21 negara anggota IORA dan 6 mitra dialog, diambil 5 teratas dari negaranegara tersebut yang dapat memenuhi kriteria regional power dan hasilnya adalah Prancis, India, Inggris, Cina, dan Amerika Serikat. Berikut data perbandingan kekuatan ekonomi yang akan dilihat dari tingkat GDP, militer, dan maritim dari kekuatan angkatan laut kelima negara tersebut:

Tabel 1. Perbandingan Kekuatan Regional Power di IORA

\begin{tabular}{|l|l|c|c|c|}
\cline { 3 - 5 } No & Negara & $\begin{array}{c}\text { Marine } \\
\text { Power } \\
\text { Ranking }\end{array}$ & $\begin{array}{c}\text { GDP } \\
\text { ( US \$) }\end{array}$ & Militer $^{\mathbf{3}}$ \\
\hline 1 & Cina & 2 & $\begin{array}{c}12.237 .700 \\
(2)\end{array}$ & 3 \\
\hline 2 & Amerika & 3 & $\begin{array}{c}19.390 .604 \\
(1)\end{array}$ & 1 \\
\hline 3 & India & 7 & $\begin{array}{c}2.597 .491 \\
(6)\end{array}$ & 4 \\
\hline 4 & Prancis & 21 & $\begin{array}{c}2.582 .501 \\
(7)\end{array}$ & 5 \\
\hline 5 & Inggris & 32 & $\begin{array}{c}2.622 .434 \\
(5)\end{array}$ & 6 \\
\hline
\end{tabular}

Sumber:

1. Total Naval Strength by Country [Online]. Tersedia di: https://www.globalfirepower.com/navy-ships.asp

2. Gross Domestic Product 2017 [Online]. Tersedia di: https://datacatalog.worldbank.org/dataset/gdpranking 2018

3. Military Strength Ranking [Online]. Tersedia di: https://www.globalfirepower.com/countrieslisting.asp

Jika dilihat dari data tersebut, Amerika unggul dalam GDP dan kekuatan militer. Sedangkan, Cina berada tepat di bawah Amerika untuk tingkat GDP dan dua tingkat lebih rendah pada kekuatan militer. Cina menduduki ranking 3 setelah Amerika dan Rusia. Kekuatan militer di dasarkan pada perhitungan jumlah angkatan dan armada perang di negara bersangkutan. Walaupun begitu, kekuatan angkatan laut Cina adalah yang terbesar dibandingkan 5 negara besar IORA dan mitra dialog. 
Sementara, dalam hal daya angkut kapal angkatan laut Cina dan Amerika, pada tahun 2017 Cina memiliki jumlah rata-rata angkutan lebih besar dibandingkan Amerika. Berikut grafik perbandingan jumlah angkutan Cina dan Amerika sebagai berikut:

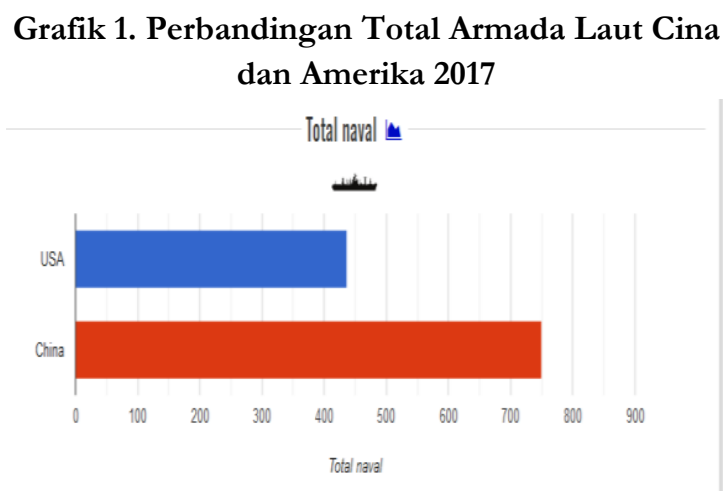

Data pada grafik di atas menunjukkan bahwa Cina memiliki lebih banyak armada laut dibandingkan Amerika. Angkatan laut Cina telah mengalami modernisasi dan terus berkembang dari tahun ke tahun. Cina memiliki sistem persenjataan modern dan sensor yang mampu menjaga keamanan dan ketahanan laut.

Hal penting yang tidak dapat dipisahkan bagi sebuah regional power di IORA adalah pengaruh dan dominasi. Tidak ada artinya bagi dinamika wilayah Samudera Hindia jika ke lima negara regional power tersebut tidak berusaha mendominasi dalam IORA. Selain Cina, India juga berupaya menyebarkan pengaruhnya di wilayah Samudera Hindia. Tidak dapat dipungkiri bahwa India juga memiliki andil yang cukup signifikan bagi perkembangan IORA. India telah banyak memberikan investasi di wilayah tersebut. Namun, Cina memiliki strategi pertahanan dengan menjalin kemitraan strategis dan kooperatif. Cina yang telah membentuk aliansi bersama Myanmar dan Pakistan, memastikan bahwa sebagian besar wilayah perbatasan India dapat dicover oleh ketiga negara tersebut. Hubungan strategis Cina dan Myanmar juga memungkinkan bagi Cina untuk mudah dalam mengontrol angkatan laut di wilayah Samudera Hindia.

Upaya dominasi Cina di IORA selain menandingi negara-negara pesaingnya, Cina juga membangun kemitraan strategis dengan neagranegara di wilayah Samudera Hindia. Selain Pakistan dan Myanmar, Cina juga menjalin kemitraan strategis dengan Iran, Bangladesh dan Sri Lanka. Bagi negara-negara mitra strategis, Cina dipandang sebagai aliansi dalam memperkuat politik di negara mereka dan merupakan pemasok senjata militer dan teknologi dengan harga terjangkau (Dutta, t.t). Sejak Cina berkosentrasi terhadap penguasaan wilayah Samudera Hindia, Cina telah mulai melakukan normalisasi hubungan dengan negara tetangganya. Cina mulai membuka negosiasi dengan Vietnam dan ASEAN terkait dengan penyelesaian 
sengketa di Laut Cina Selatan. Hubungan ekonomi dan politik juga mulai dibenahi di Asia, sehingga saat ini Cina dapat menjadi pemain utama dalam perdagangan di Asia (Dutta, t.t).

\section{STRATEGI MARITIM CINA MELALUI IORA}

Keterlibatan Cina dalam IORA tidak hanya sebagai upaya mencapai kepentingan nasionalnya tetapi juga peluang untuk menjadi regional power dalam kohesi regional tersebut. Meskipun statusnya saat ini bukan anggota tetapi hanya mitra dialog, namun kedekatan geografisnya dengan Samudra Hindia, keseriusan Cina terhadap bidang Maritim, ditambah dengan ekonominya yang kuat, Cina sangat berpeluang menjadi regional power di IORA.

Bagi Cina IORA adalah badan multilateral yang sangat signifikan (Nolte, 2010: 890). Cina telah membangun strategi dalam rangka mencapai kepentingan nasionalnya. Strategi yang dibangun tidak hanya strategi biasa, namun strategi sebagai sebuah kekuatan besar (great power). Hal tersebut ditunjukkan dengan komitmen Cina untuk mengamankan wilayah sekitar Samudera Hindia. Menjalin kemitraan strategis dengan negara-negara di sekitar samudera Hindia merupakan strategi yang cukup aman untuk menghindari konflik. Dalam upaya menguasai Samudra
Hindia, Cina lebih mengedepankan strategi kerja sama yang ia wujudkan dengan bergabung dalam mitra dialog IORA. Di dalam Chinese Defence White Paper yang dirilis pada tahun 2013, Cina menyatakan untuk melindungi kepentingan dan hak-hak maritime nasional serta menyediakan angkatan bersenjata yang memadahi untuk mengamankan kepentingan tersebut. Ada tiga dimensi strategi Cina di IORA, yaitu : a) menjalin kemitraan strategis dan kooperatif dengan negaranegara di pesisir Samudera Hindia; b) modernisasi angkatan laut secara cepat; c) meningkatkan penyebaran angkatan laut secara strategis di kawasan Samudera Hindia.

Terdapat tiga kepentingan Cina di IORA, ekspansi pasar internasional, energi, dan komunikasi (Hong, Ciyuan, 2018). Pertama, melihat tren perdagangan Cina dengan negaranegara IORA menunjukkan tren positif di mana angkanya terus naik dari tahun ke tahun. Cina memiliki banyak bahan baku baik mentah maupun barang jadi yang siap diekspor ke negara-negara IORA. Tidak hanya smber daya alam yang memadai, sumber daya manusia juga cukup menjanjikan di Cina. Tidak heran jika pertumbuhan ekonomi Cina cepat mengalami kenaikan.

Kedua, sebagai negara industri Cina membutuhkan energi yang cukup besar untuk mencukupi permintaan di 
dalam negeri. Timur Tengah dan Afrika Selatan merupakan dua negara yang berperan besar bagi penyedia kebutuhan energi Cina. Cina sangat berkepentingan di wilayah Samudera Hindia sebagai jalur pasokan energi bagi negaranya. Dalam hal ini, Cina menjadi konsumen minyak dan gas terbesar bagi Teheran. Bantuan Cina di Afrika Selatan juga untuk memperlancar pasokan minyak dari Afrika Selatan ke Cina.

Ketiga, dilihat dari sisi keamanan, Cina memiliki tanggung jawab terhadap Maritime Cooperation Declaration yang disahkan pada tahun 2014. Deklarasi tersebut merupakan bukti komitmen Cina untuk mengamankan Samudera Hindia dengan melakukan pengawasan dengan menindak perbuatan melanggar hukum laut, seperti penangkapan ikan secara ilegal, pembajakan, perdagangan manusia, bencana alam dan perubahan iklim. Selain itu, keamanan wilayah Samudra Hindia juga bertujuan sebagai upaya membangun komunikasi dengan negara-negara di wilayah Samudera Hindia.

Menurut Azhar Ahmed (2014) dalam tulisannya berjudul "Maritime Powver and Strategy" untuk mewujudkan kekuatan maritim, suatu negara harus memiliki kapasitas maritim nasional yang terdiri dari empat elemen yaitu pelabuhan, armada niaga, sumber daya laut dan armada angkatan laut serta kemitraan strategis. Oleh karena iu, Cina juga harus memiliki kapasitas maritim nasional.

Adapun kapasitas maritim nasional Cina antara lain, pertama, pelabuhan menjadi elemen penting bagi strategi maritim Cina. Para ilmuan menyebut ambisi Tiongkok sebagai string of pearls yang mengandung arti jaringan militer dan fasilitas komersial yang dibangun Cina bersama dengan negara-negara di wilayah Samudra Hindia. Fasilitas atau infrastruktur yang dibangun Cina meliputi pelabuhan, baik militer maupun komersil. Cina membangun pelabuhan di beberapa negara seperti Pakistan (Gwaadar dan Pasni) dan membangun stasiun pengisian bahan bakar di Hambantota, Sri Lanka. Selain itu, Cina juga menyediakan bantuan finansial untuk membangun pangkalan kargo serta mendukung operasi militer di Maladewa (Dutta, t.t). Infrastruktur ini berkontribusi terhadap proyeksi kekuatan Cina di Samudera Hindia. Pembangunan infrastruktur tersebut selain untuk menguasai jalur pasokan energi, tujuan utamanya adalah mendukung kemampuan angkatan laut.

Kedua, menurut data CLA World Factbook, armada niaga Cina menjadi armada niaga terbesar ketiga di dunia di bawah Panama dan Liberia (Blasko, 2015, 5). Armada niaga Cina terus 
berkembang dan menjadi elemen penting bagi kekuatan maritim Cina. Pada periode Mao, armada niaga tidak terlalu diperhatikan sehingga tidak cukup berkembang. Setelah reformasi yang dilaukan Deng Xiaoping, armada niaga Cina mulai berkembang. Total kapasitas angkutan armada niaga Cina mencapai 142 juta ton dan mencapai 8\% dari total kapasitas angkutan dunia (Blasko, 2015, p. 5).

Cina memberikan bantuan fasilitas militer kepada angkatan militer Myanmar, tujuannya tidak hanya untuk masalah keamanan tetapi juga peningkatan perdagangan di wilayah Samudera Hindia. Wilayah strategis lainnya disekitaran Samudera Hindia adalah Selat Malaka. Pada tahun 2005, Malaysia menjadi partner perdagangan terbesar keempat bagi Cina. Keduannya menandatangani Memorandum of Understanding on Defence Cooperation sebagai respon atas hubungan kedua negara dengan mempertimbangkan pentingnya Selat Malaka. Di bawah memorandum tersebut kedua negara melakukan latihan militer bersama, melakukan pertukaran personel dan berkomitmen untuk melakukan dialog hubungan keamanan kedua negara (Dutta, t.t). Selain strategi keamanan militer, penguasaan wilayah dekat Selat Malaka bertujuan untuk keamanan perdagangan Cina-Malaysia. Hal tersebut menunjukkan peningkatan aktivitas Cina di wilayah sekitar Samudera Hindia.

Ketiga, eksplorasi sumber daya laut Samudra Hindia telah dilakukan Cina sejak kekaisaran Zhang He. Cina melakukan perdagangan khususnya di India dan Asia Tenggara melalui Samudera Hindia. Kegiatan terbaru yang dilakukan Cina adalah eksplorasi dengan menggunakan alat AUV (Autonomus Underwater Vehicle) yang akan melakukan ekspedisi sejauh $325 \mathrm{~km}$ menyusuri Samudera Hindia. Ekspedisi ini bertujuan untuk mendeteksi endapan bahan kimia sulfida polimetalik di daerah eksplorasi barat daya Samudera Hindia.

Keempat, armada angkatan laut Cina telah mengalami proses modernisasi. Modernisasi tersebut terlihat dari pengantian teknologi lama menjadi teknologi baru. Beberapa yang diganti atau ditambah beberapa contohnya seperti kapal pengangkut, kapal pengawal, amphibi, kapal penghancur, dan korvet. Cina juga telah membangun instalasi radar baru di pulau Hiangyi serta mambangun infrastruktur angkatan laut di Akyab dan Mergui, Myanmar. Strategi ini dimaksudkan untuk monitoring komunikasi angkatan laut India dan kemungkinan India melalukan uji coba misilnya di lembah Bengal.

Keempat elemen tersebut menjadi penting dikelola oleh Cina 
sebagai syarat menjadi maritime power di IORA. Selain keempat elemen tersebut Cina juga memiliki potensi besar seperti letak geografis yang strategis, ukuran teritorial dan jumlah populasi yang besar, dan institusi politik yang cenderung stabil. Politik otoriter menjadi salah satu nilai positif bagi Cina untuk membangun power maritimnya. Dengan kontrol penuh dan sikap tegas dari pemerintah, strategi maritim Cina dapat lebih mudah diwujudkan.

\section{KESIMPULAN}

Keterlibatan Cina di IORA merupakan bagian dari strategi Cina untuk menjadi kekuatan maritim dunia. Strategi tersebut diwujudkan dengan menjalin kerja sama dengan mitra strategis di wilayah Samudra Hindia dan memperkuat armada angkatan laut. Dengan melihat data kekuatan negara-negara anggota dan mitra dialog IORA, terlihat bahwa Cina menguasai sebagian besar kekuatan baik ekonomi maupun maritim. Oleh karena itu, Cina berpotensi menjadi maritim power di IORA.

Bagi Cina IORA adalah badan multilateral yang sangat signifikan. Strategi yang dibangun tidak hanya strategi biasa, namun startegi sebagai sebuah kekuatan besar (greatpower). Hal tersebut ditunjukkan dengan komitmen Cina untuk mengamankan wilayah sekitar Samudera Hindia.
Menjalin kemitraan strategis dengan negara-negara disekitar samudera Hindia merupakan strategi yang cukup aman untuk menghindari konflik. Cina lebih mengedepankan strategi kerja sama yang ia wujudkan dengan bergabung dalam mitra dialog IORA. Selain kemitraan strategis, upaya Cina sebagai maritime power di IORA diwujudkan dengan memaksimalkan potensi Samudera Hindia, karena letak geografis Cina tidak secara langsung berbatasan dengan Samudera Hindia, maka Cina membutuhkan mitra strategis untuk dapat menempatkan armada lautnya di wilayah Samudera Hindia. Cina membangun pelabuhan, baik militer dan komersil, meningkatkan hubungan perdagangan dengan negara-negara mitra, melakukan ekplorasi diwilayah Samudra Hindia, dan memodernisasi armada angkatan lautnya.

\section{REFERENSI}

Ahmad, Azhar. (2014) "Maritime Power and Strategy", NDU Journal, XXVIII, pp. 23-41 (Online). Tersedia di: www.ndu.edu.pk/issra/issra_pub/arti cl es/ndu.../02-Maritime-Power-\&Strategy.pdf (Diakses: 16 Juli 2018).

Blasko, Dennis J. (2015) 'Cina Merchant Marine, CNA Conference Facility, Cina as Maritime Power', Working Paper Series (Online). Tersedia di: https://www.cna.org/cna_files/pdf/c i na-merchant-marine.pdf (Diakses: 28 Juli 2015).

Dutta, Sujit. (t.t) Cina Emerging Power and Military Role: Implication for South Asia 
[online]. Tersedia di:

https://www.rand.org/content/dam/ rand/pubs/conf_proceedings/CF137 /C F137.chap5.pdf (Diakses: 17 Juli 2018).

Hong, Wei dan Li Ciyuan. (2018) Indian Ocean Rim Association: New Developments and Cina's Engagement (Online).

Tersedia di:

https://www.pressreader.com/cina/ci $\mathrm{n}$ a-international-studiesenglish/20180520/281526521728952 (Diakses: 17 Juli 2018).

Indian Ocean Rim Association for Regional Cooperation (IORARC). (2013)

(Online). Tersedia di: https://www.mea.gov.in/Portal/Fore ig nRelation/IORARC.pdf (Diakses: 18 Mei 2018).

Indian Ocean Rim Association. (2017) (Online). Tersedia di: http://www.iora.int/en/about/aboutiora (Diakses: 18 Mei 2018).

Issac B. Kardon. (2015) Cina's Maritim Rights and Interests: Organizing To Become a Maritim Power (Online). Tersedia di: https://www.cna.org/cna_files/pdf/c i na-maritim-rights.pdf (Diakses: 15 Mei 2018).

Kapoor, Latesh \& Bajpai, A. (2018) Contemporary Geo-Politics of Indian Ocean : India, Cina and Other Powers (Online). Tersedia di: http://paperroom.ipsa.org/papers/pa p er_29648.pdf (Diakses: 15 Mei 2018).

Nolte, Detlef. (2010) "How to Compare Regional Powers: Analytical Concepts and Research Topics", Review of International Studies. International Studies Association.
Oatley, Thomas. (2012) International Political Economy, 5th edition, New York: Pearson.

Ross, Ross. (2017) Why Are Cina and India Growing So Fast? State Investment (Online). Tersedia di: https://www.huffingtonpost.com/joh n_ross-/cina-indiagrowth_b_11655472.html (Diakses: Mei 2018).

Roza, Rizki. (2015) Indian Ocean Rim Association (IORA) dan Kepentingan Indonesia di Samudera Hindia (Online). Tersedia di: http://berkas.dpr.go.id/puslit/files/in fo_singkat/Info $\% 20$ Singkat-VII-6-IIP3DI-Maret-2015-75.pdf (Diakses: 15 Mei 2018).

Waidyatilake, Barana. (2017) The Indian Ocean Rim Association, Scaling Up? (Online).

Tersedia di:

https://www.isas.nus.edu.sg/wpcontent/uploads/media/isas_papers/ ISAS $\% 20$ Working $\% 20$ Papers $\% 20$ No. $\% 20262-$

$\% 20$ The $\% 20$ Indian $\% 20$ Ocean $\% 20$ Ri m\%20Association.pdf (Diakses: 15 Mei 2018).

Wan, Ming. (2008) The Political Economy of East Asia: Striving for Wealth and Power, Washington: CQ Press.

Yi-Min Lin. (2014) Between Politics and Market: Firms, Competition and Institutional Change in Post-Mao Cina, New York: Cambridge University Press. 